\title{
A Social Semiotic Analysis of Register Variables in the Indonesian Government-Distributed English Textbook
}

\author{
${ }^{1}$ Elih Sutisna Yanto, ${ }^{2}$ Hikmah Pravitasari \\ ${ }^{1}$ English Education Department, Universitas Singaperbangsa Karawang, Karawang West Java, \\ Indonesia \\ ${ }^{2}$ English Education Study Program, STKIP La Tansa Mashiro, Rangkasbitung Lebak Banten, \\ Indonesia
}

\begin{abstract}
While the inclusion of Genre-Based Approach (GBA) as language pedagogy globally has received extensive attention in recent years, research on evaluating ELT textbooks focusing on the register representation remains relatively scarce. Drawing on the framework of social semiotic text analysis as the functional variety of language and register theory: field, mode and tenor, the present study aimed to explore Indonesian Ministry of Education and Culture-endorsed secondary school English textbook from the perspective of textbooks as "a resource for making meaningslanguage as a social semiotic." The findings revealed that language textbooks should be viewed as sociocultural artifacts that feature register or the context of situation representation. This article examines the research question in what ways register variables are portrayed in one Indonesian Ministry of National Education-approved secondary school English textbook, which deploys various genres and discursive resources. This critical analysis reveals that verbal texts with different genres in the textbook represent a myriad of contexts of which both teachers and students need to become aware. The implication of this study suggests that both teachers and students need to equip with skills in analyzing and reading as well as in critical language awareness analysis. Both teachers and students should have the opportunity to engage critically with textbooks as a socio-semiotic agent, for instance.
\end{abstract}

Keywords: English textbook, genre-based approach, socio-semiotic analysis, systemic functional linguistics

\section{ABSTRAK}

Pendekatan Berbasis Genre (GBA) sebagai pedagogi bahasa secara global telah mendapatkan perhatian yang luas dalam beberapa tahun terakhir. Penelitian tentang mengevaluasi buku teks Pengajaran Bahasa Inggris yang berfokus pada representasi register masih relatif langka. Berdasarkan kerangka analisis teks semiotika sosial sebagai ragam fungsional bahasa dan teori register: medan, moda dan pelibat. Penelitian ini bertujuan untuk mengeksplorasi buku teks bahasa Inggris sekolah menengah yang disetujui oleh Kementerian Pendidikan dan Kebudayaan Indonesia dari perspektif buku teks sebagai "Sumber untuk membuat makna-bahasa sebagai semiotik sosial." Temuan mengungkapkan bahwa buku teks bahasa harus dipandang sebagai 
artefak sosiokultural yang menampilkan register atau konteks representasi situasi. Artikel ini membahas pertanyaan penelitian dengan cara apa variabel register digambarkan dalam satu buku teks bahasa Inggris sekolah menengah yang disetujui Kementerian Pendidikan Nasional Indonesia, yang menggunakan berbagai genre atau jenis teks dan sumber diskursif. Analisis kritis ini mengungkapkan bahwa teks verbal dengan genre yang berbeda dalam buku teks mewakili segudang konteks yang perlu disadari oleh guru dan siswa. Implikasi dari penelitian ini menunjukkan bahwa baik guru maupun siswa perlu dibekali dengan keterampilan dalam menganalisis dan membaca serta dalam analisis bahasa kritis. Baik guru dan siswa harus memiliki kesempatan untuk terlibat secara kritis dengan buku teks sebagai agen sosio-semiotik, misalnya.

Kata Kunci: analisis semiotic sosial, buku teks bahasa Inggris, pendekatan berbasis genre, linguistik sistemik fungsional

\begin{tabular}{|l|l|l}
\hline Received: December 20, 2021 & Accepted: February 17, 2022 & Published: February 21, 2022
\end{tabular}

How to cite:

Yanto, E.S., \& Pravitasari, H. (2022). A social semiotic analysis of register variables in the Indonesian government-distributed English textbook. English Learning Innovation, 3(1), 42-69 https://doi.org/10.22219/englie.v3i1.19288

\section{INTRODUCTION}

Globally, the use of Genre-based approaches as language pedagogy focusing on the understanding and production of selected genres of texts has been a main trend in English language teaching (ELT). Derewianka (2003) contends that this Genre-based pedagogy has become increasingly dominant in majority ELT such as primary, secondary, tertiary, and professional contexts in countries as diverse as Singapore, South Africa, USA, Italy, Hong Kong, Australia, UK, China, Canada, Sweden and Thailand. In the context of Indonesian English language pedagogy, particularly in secondary schools, textbooks used commonly adopt genre-based teaching approaches. The design of genre-based teaching and learning cycles is informed by studies in language development (see, Halliday, 1975, Painter 1999) showing that successful language learning depends on "guidance through interaction in the context of shared experience" (Rose \& Martin, 2012, p58).

Textbooks as silent partners (Orton 2010) shape interaction between students, teachers, and instructional kits. This educational artifact is also called a structured and enacted curriculum that guides instructional activities and tasks on which both students and teachers work (Widodo, 2016). From a social semiotic, textbooks are viewed as "a resource for making meanings_-language as a social semiotic.” (Mickan, P., \& Lopez, E. 2016, p. 3). A social semiotic perspective on English textbook examines how with text students and teachers engage in acts of meaning. "Acts of meaning are the linguistic instances of the linguistic system of meaning potential. In other words, acts of meaning are a subclass of 
semiotic, acts that are semantic" (Webster, 2009, p.5). Practically, people use language to do different social acts by talking, listening, reading and writing. From a Hallidayan social semiotic perspective, functions of language include "experiential (representing experience of the world), logical (creating logical connections among various elements of a text to create a coherent whole), interpersonal (enacting social roles/role identities), and textual ( creating a coherent whole)" (Widodo, 2015, p.31). These general groups of meaning are all connected in the structure of discourse. This implies that textbooks are an instructional guide that assists learners engage with "conventions of text, with the organisation of text types, and with wording selection of text types appropriate to context makes possible verbal participation in the social practices of communities" (Mickan, P. 2017, p. 18).

Thus, instructional textbooks always bring "the interrelationship of text and contextthe social function of the text aligned with the lexicogrammar of the text type or genre"(Mickan, P. 2017, p.18). These features should be represented or discursively constructed in ELT textbooks, for instance. In order to unpack these features in ELT textbooks, the authors argue that a critical social semiotic analysis of textbooks would give a broader and more detailed description of the register or the context of situation representation constructed in the textbooks. To date, there is a little study examining register representation in Indonesia's secondary school English textbook(s) from a critical social semiotic perspective. For this reason, we would like to contribute a better understanding of in what ways register representation are discursively represented in this textbook so that teachers and students gain heightened awareness that any texts in textbooks contain "the function and social context of text types or genres as realised in their structure and wording" (Mickan, P.2017,p.18). In this respect, both students and teachers play critical roles as textbook assesors who see English textbooks as the resources of language, text and context.

The present chapter is structured as follows. First, it touches on the role of social semiotics perspective in language learning. It moves on to previous research on register representation in school English textbooks. Then, we would like to present methodological considerations and discussions. Both pedagogical and empirical implications are also presented to furnish language teachers with insight into pedagogical worth of this analysis. Drawing on this implication, language researchers interested in the closer textual investigation into English textbooks can extent this scholarship. The outcome of this textual analysis can be a catalyst for designing social semiotic-based language materials locally situated in particular education contexts. The article aims to answer the question in what ways 
register variables is portrayed in one of Indonesian Ministry of National Education-approved secondary school English textbooks?

\section{The Role of Social Semiotic Perspective in Language Learning}

Social semiotic theory is an interdisciplinary model of language and language learning, which "sits at the intersection between linguistics, anthropology, sociology, and education (Halliday, as cited in Teramoto, 2010, p.45). The focus on language as a social semiotic draws on systemic functional linguistics (SFL) (Halliday and Matthiessen 2014) and it is adopted here as the model which enables the explicit and detailed description and analysis of texts in social life. Halliday and Hasan (1989) suggest that this social semiotic perspective tries to operate systemic linguistics to educational study. Widodo (2015, p.31) asserts that "social semiotic theory at the heart of educational linguistics provides fresh insight into the nature of language and language learning." Social semiotic theory is a functional semantic theory of language that informs how people use language to make meaning (Halliday \& Mattiessen, 2004). They write "Language is, in the first instance, a resource for making meaning; so text is a process of making meaning in context." (Halliday and Matthiessen 2014, p. 3). The study of texts has been widely applied in education, in institutional and workplace communication, in media and the study of personal communication (Bowcher 2012; Butt et al. 1994; Christie and Derewianka 2008; Hasan 1996; Martin 2009; Martin and Rose 2004, 2007; Coffin and Donohue 2014; Williams 2004).

Language as a social semiotic or as a human resource for the expression and understanding of meanings refers to authentic language use as acts of meaning, situated in socio-cultural context tailored with social practices. The distinctive feature is the interrelationship of texts with the practices of communities as illustrated in Fig.1 


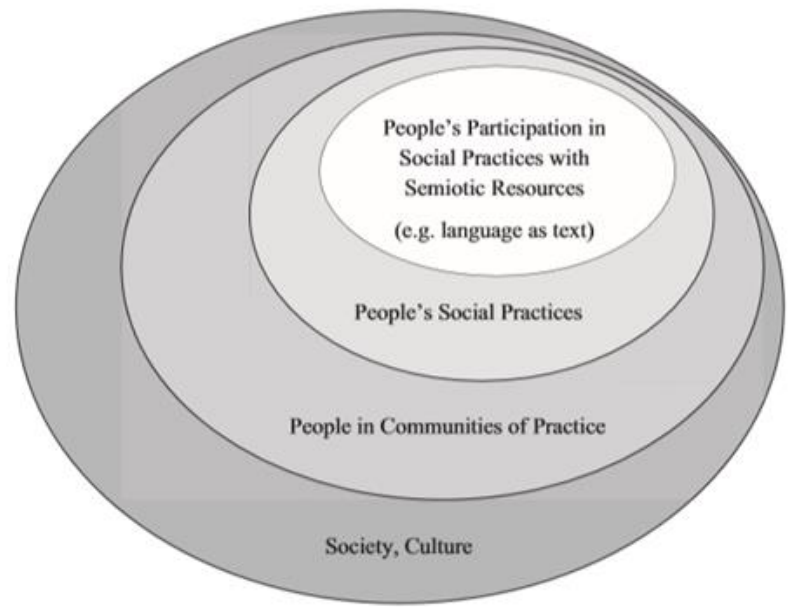

Figure 1. People's participation in Society (Mickan 2013, p.34)

Figure 1 illustrates "the interrelationship of human activity and language use in society with language a resource for participation in practices of communities. With texts, we take part in many different communities with defined and potential language practices - as chef, accountant, journalist, child carer, and teacher. We vary the texts according to the social practices of family roles and societal positions in workplaces, professions and governance. The striking feature of our experience of texts is that we recognise the function and social context of text types or genres as realised in their structure and wording." (Mickan, 2016, p.18).

From a functional perspective, there are at least two major aspects in learning a language-learning how to mean, and learning how to mean in different context of situations or registers as the functional variety of language. First, learning a language means learning how to mean in the language (Halliday \& Matthiessen 2014). Meaning-making is the heart of language learning, especially as it connects to how to make different texts function in different contexts. Mastering different types of texts operating in different contexts can support learners to make full use of the linguistic resources in meaning- making. Second, learning a language also means accumulating different registers or context of situations operating in different contexts, consequently gradually expanding one's registerial stock (Matthiessen 1999). In order to expand their learners' registerial repertoires, language instructors must empower learners by facilitating their engagement with different types of texts in different contexts (Xuan, 2017). 
Learning language is learning to understand meaning in text and to select and use the appropriate genre and lexicogrammatical resources in order to participate in sociocultural activities. Learning language also developes the resources of the system of a language for the expression and comprehension of potential meanings. "This is a process of socialisation which takes advantage of students' ability to use semiotic language resources from prior experience of, and exposure to, a wide range of texts" (Widiastuti, R. 2017,p.181). The implementation of a social semiotic framework to the conceptualisation of learning to mean places people's meanings at the centre of experience, with language as a fundamental resource for expressing meanings (Mickan 2006, Widiastuti,R,2017). In addition, Mickan (2017) added that "social semiotic pedagogy is based on students' engagement with real texts or authentic texts embedded in context. Learners engage in the comprehension of texts and the expression of meanings in texts as acts of meaning" (p.26). For this reason, learners can be aware of how they accomplish their lives with varied discourses or text types or genre. Mickan (2017, p.25) contends that "the centre of language learning is a comprehension of meanings and expression of potential meanings with texts responsive to social contexts".

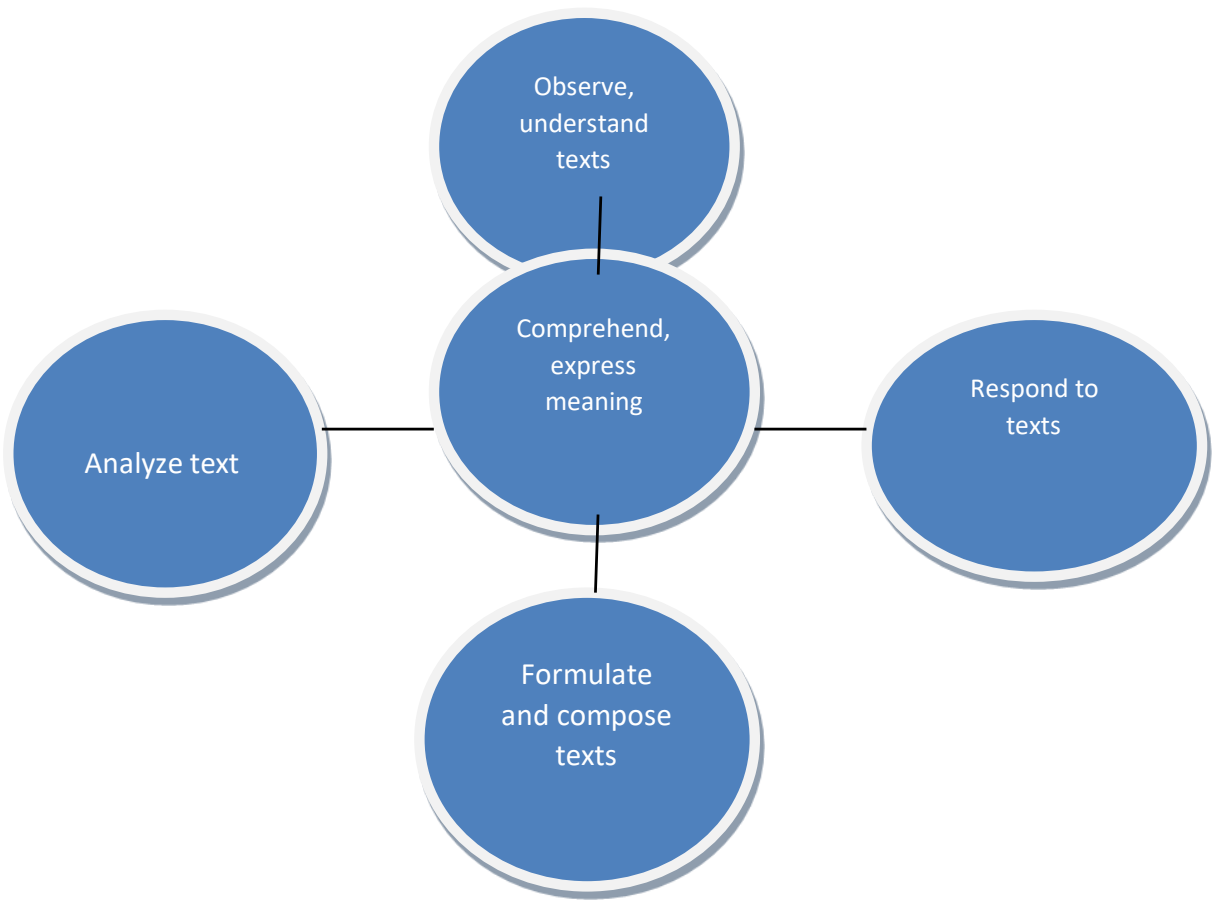

Figure 2. Working with texts (Mickan, 2017,p.26)

Widodo (2015, pp33-34), as illustrated in Fig.3, contends that "there is the relationship between text and context. The smallest unit of texts is phonology (spoken) or 
graphology (written). As Feez \& Joyce (1998, p.7) assert that " Once meanings become words and structures, it can be expressed as speech or writing using an economical number of sounds or symbols". Lexico-grammar is the unit of meaning at a clausal level. This is the level which gives human language its creative power and its complexity (Feez \& Joyce, 1998). It is a resource for conveying ideational, interpersonal, and textual meaning. The key unit of text is semantics and pragmatics or discourse semantics. Discourse pertains to meaning and function. The text is an intersubjective stretch of language where involved interactants exchange meaning in a context of situation and in a context of culture. These discourses may convey ideological values or beliefs (e.g., ways of doing, being, relating, and behaving). Texts move beyond linguistic resources. They entail social, cultural and ideological meanings."

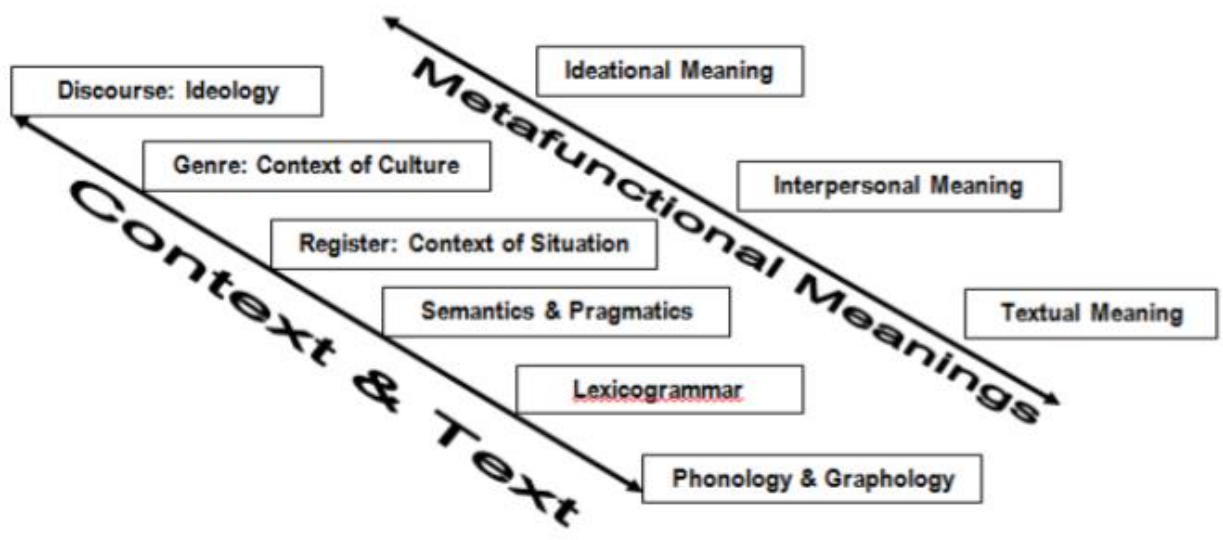

Figure 3. The Stratal Perspective of Language in SFL (Widodo, 2015, p.33)

\section{Previous Research on Register Representation in English School Textbooks}

There is a considerable body of studies, specifically investigating sociosemiotic issues in language textbooks in different countries such as Korea, Bulgaria, China, Indonesia, Ireland, Mauritius, Morocco, Namibia, Norway, Romania, South Korea, Sri Lanka, Singapore and Vietnam, have been documented in different countries such as Korea, Bulgaria, China, Indonesia, Ireland, Mauritius, Morocco, Namibia, Norway, Romania, South Korea, Sri Lanka, Singapore and Vietnam Since 2000. For example, the evaluations of international textbooks by Tomlinson (2012) and Gilmore (2015) illustrate the continued representation of language separated and extracted from text and context, despite the knowledge that decisions about the lexicogrammar of texts are dependent on selection at the 
semantic level of text type appropriate to social context. The lack of authentic texts and of meaning-making activities in textbooks is evidence of the persistence of structural grammar instruction. In a critical review of the value of practice exercises in different domains of human activity, Macnamara et al. (2014) question the value of decontextualised practice exercises, which colonise foreign and second language textbooks.

A further problem has been identified by Lim (2007) in the analysis of a mandated textbook for teaching English in Korea. Fabricated texts for displaying a grammatical point in fact modelled misleading grammar. The model text lacked cohesion, correct grammatical use and authenticity. The use of artificial language models, of grammar detached from context and unrelated sentence-level exercises are wasted opportunities for development of discourse skills. Schleppegrell (2008) evaluated the register features of texts taken from a junior school science textbook. The evaluation were made on the three contextual variables of field, tenor and mode. In terms of field, Schleppegrell (2008) found that science textbooks usually use complex nominal syntax with specialized, technical and abstract lexis; and material and relational processes to enable clause-internal reasoning with nouns, verbs and prepositions, instead of conjunctions. In terms of tenor, her finding was that the textbooks prefer to use declarative mood and modal verbs to realize reasoned judgments, and implicit evaluation through attitudinal resources of appraisal to realize the expert and authoritative roles of the textbook writers. Finally, in terms of mode, science textbooks consentrate information through a collection of resources including clause-combining strategies, e.g. embedding, theme position marking clause organizational structure, nominalization as well as other forms of grammatical metaphor (Schleppegrell, 2008). Widiastuti (2017) investigated a unit of work in an Indonesian textbook. She found that scaffolding activities were not presented. Affordances to create potential meaning making were removed as activities were not accompanied with descriptive analysis of genre and of lexicogrammar appropriate to the function of a text, such as writing a pamphlet.

The section of the textbook examined in this study was on a relevant topic for students in Indonesia. However, teachers need to adapt and modify the texts and tasks in order for students to engage in acts of meaning with texts on the topic. In addition, Putra, D. A., \& Lukmana, I. (2017) investigated text complexity progression in the reading texts of English textbooks published for senior high school students in Indonesia. The nature and rate of that progression are addressed within the framework of Systemic Functional Linguistics. Being largely qualitative, this study examines three consecutive textbooks issued by the Ministry 
of Education, which are available online for classroom use. Data were collected and sampled from the reading texts found in the textbooks and were analyzed with regard to lexical density, lexical variation and grammatical intricacy in order to find the complexity of the texts. The results of the analyses show that regardless of the inconsistent progression of text complexity within each textbook, there is a consistent pattern of text complexity progression across grade levels. In other words, the lexical density, lexical variation and grammatical intricacy across the textbooks were found to have consistent progression from one grade level to another of which the direction is positive. Recently Widodo (2018) undertook critical micro-semiotic discourse study examines in what ways values are portrayed in one Indonesian Ministry of National Education-approved secondary school English textbook, which deploys various lexico-grammatical and discursive resources. He reported that visual artifacts and verbal texts with different genres in the textbook represent a myriad of values of which both teachers and students need to become aware. He also suggests that both teachers and students need to equip with skills in critical thinking and reading as well as in critical language awareness analysis. For example, both teachers and students should have the opportunity to engage critically with textbooks as a value agent.

\section{METHOD}

The present study proposes a framework of social semiotic text analysis informed by Systemic Functional Linguistics-related construct (e.g., genre, register theory: field, mode and tenor, and meta function of meaning) because it examines genres or text types of textbooks. In this study, one textbook, "Bahasa Inggris for Senior High School Grade XII" (general programme) by Utami Widiati, Zuliati Rohmah, and Furaidah was selected for a more in-depth analysis based on the following criteria:

1. this book uses The 2013 ELT Curriculum that recognized the application of Halliday's three metafunctions: ideational, interpersonal, and textual to the teaching of four skills, such as listening, speaking, reading, and writing.

2. this textbook is nationally adopted because this textbook is endorsed by the Indonesian Ministry of National Education and culture;

3. the textbook, licensed for use in Indonesian schools, was written for senior high school students aged 16-17 years in year 12

4. the textbook follows specifications of a genre-based text (2013), combining Genre Based Assessment (GBA) and Communicative Language Teaching (CLT). 
5. the textbook was written by Indonesian writers who understand the context of ELT in Indonesia.

McDonough \& Shaw (as cited in Kontozi A 2011) claim that one or two selected units should be sufficient for close analysis. The theme for chapter 3 is "Creating caption", and the sub-theme is "Warmer: video watching"; Reading caption; "Writing and describing captions"; and the lesson is ended by reflection to know the students' learning progress. The theme for chapter 5 is "who was involved?" and the sub-theme is "Warmer: group share; vocabulary builder; listening task; reading; vocabulary exercise; grammar review; text structure; writing enrichment and communicating. While the theme for chapter 9 is "Do it Carefully" with the sub-theme is "Warmer; reading; vocabulary builder; pronunciation practice; grammar review; text structure; speaking; writing; vocabulary exercise and reflection.

These chapters have been selected for two reasons. The first is a very pragmatic one: texts written in these chapters are short and because the authors are concerned with whole texts rather than isolated fragments of language, it is important that we are able to explore register in the context of whole texts. Longer texts would be beyond the scope of a book of this size to explore in a comprehensive way. In addition, language learners use meanings and grammatical structures that are comparatively easy. The second reason for our selection is perhaps more significant for those of us who work in language education. In the early years of schooling young learners are building foundation knowledge about language and its use. This foundation knowledge becomes the basis for their future development in language and literacy. It is in texts such as these that language educators can see what underpins English language development at all levels. (Butt, D., Fahey, R., Feez, S., Spinks, S., \& Yallop, C. , 2000)

\section{FINDINGS AND DISCUSSION}

In analysing the chosen texts, the authors utilize these three parameters in order "to show how contextual variables govern the language variety or register of a text, and how the words and grammatical structures of a text give these variables substance in the text." (De Joyce, H. S., \& Feez, S., 2016, p.59). In general, texts belong to the same text type if texts have the same sorts of meanings and/or the same structural elements. In particular, texts belong to the same register if they have meanings in common and texts with required structural elements in common are said to belong to the same genre. 
Table 1. The representation of register varibales (Field, Tenor, Mode) in the textbooks Bahasa Inggris for Senior High School Grade XII.

\begin{tabular}{|c|c|c|c|c|c|}
\hline \multirow[t]{2}{*}{ Chapter } & \multirow[t]{2}{*}{ Theme } & \multirow{2}{*}{$\begin{array}{l}\text { Location/ } \\
\text { page }\end{array}$} & \multicolumn{3}{|c|}{ Register Variables (Context of Situation) } \\
\hline & & & Field & Tenor & Mode \\
\hline 3 & $\begin{array}{l}\text { Creating } \\
\text { Captions } \\
(\text { Text } 1)\end{array}$ & p.34 & $\begin{array}{l}\text { - } \text { relational } \\
\text { processes } \\
\text { - participants } \\
\text { mostly nouns } \\
\text { - circumstances: } \\
\text { place, manner }\end{array}$ & $\begin{array}{l}\text { - declarative clause } \\
\text { - modal auxiliary } \\
\text { and lexical verb } \\
\text { - intensity of } \\
\text { modality is low }\end{array}$ & - linear theme \\
\hline 5 & $\begin{array}{l}\text { Who was } \\
\text { Involved? } \\
\text { (Text 2) }\end{array}$ & p.68 & $\begin{array}{l}\text { - verbal } \\
\text { processes } \\
\text { - participants } \\
\text { mostly nouns } \\
\text { - circumstances: } \\
\text { place, time, } \\
\text { cause, angle }\end{array}$ & $\begin{array}{l}\text { - } \text { declarative clause } \\
\text { - modal auxiliary } \\
\text { and lexical verb } \\
\text { - intensity of } \\
\text { modality is } \\
\text { medium }\end{array}$ & - marked theme \\
\hline 9 & $\begin{array}{l}\text { Do It } \\
\text { Carefully! } \\
\text { (Text 3) }\end{array}$ & p. $120-121$ & $\begin{array}{l}\text { - } \quad \text { action } \\
\text { processes } \\
\text { - participants } \\
\text { mostly } \\
\text { pronouns } \\
\text { - circumstances: } \\
\text { place, time, } \\
\text { manner, cause, } \\
\text { accompanimen } \\
\text { t, angle }\end{array}$ & $\begin{array}{l}\text { - declarative clause } \\
\text { - lexical verb } \\
\text { - no modality }\end{array}$ & - linear theme \\
\hline
\end{tabular}

\section{Verbal (Written) Portrayal (with Visual Accompaniment) of Register}

In analyzing the ideational, interpersonal, and textual meaning of the three selected texts, the authors divided the selected text into clause level. Text 1, Text 2 and Text 3 have eleven sentences which are clearly recognizable by the punctuation. Here, the writers divided Text 1 into seventeen clauses, Text 2 into twenty five clauses and Text 3 into twelve clauses (see table 2). The three selected texts were analyzed based on functions of language: the ideational, interpersonal, and textual meaning of the text. From a Hallidayan social semiotic perspective, functions of language include experiential meanings (representing experience of the world), logical meanings (creating logical connections among various elements of a text to coherent whole). Together experiential and logical meanings make up the ideational meanings of a text, which are a reflection of a field. Interpersonal meanings (enacting social roles/role identities) enable us to interact with others and to express a point of view, a reflection of tenor, and textual meanings (creating a coherent whole) the ideational and interpersonal meanings together into a cohesive, comprehensible, and coherent whole, a reflection of mode. "These three types of meanings are made real, or given substance in a 
text, through the choice and arrangement of language features" (De Joyce, H. S., \& Feez, S., 2016, p.59).

Table 2. Number of Clauses and Words Analysed in the textbook Bahasa Inggris for Senior High School Grade XII

\begin{tabular}{lcccc}
\hline & Text 1 & Text 2 & Text 3 & Total \\
\hline Clauses & 17 & 25 & 12 & 54 \\
Percentage & $31.5 \%$ & $46.3 \%$ & $22.2 \%$ & $100 \%$ \\
Words & 187 & 247 & 133 & 567 \\
Percentage & $32.9 \%$ & $43.6 \%$ & $23.5 \%$ & $100 \%$ \\
\hline
\end{tabular}

Text 1: Creating Captions (Chapter 3, p.34)

(C1) A caption, also known as a cutline, (C2) is a text that appears below an image. (C3) Most captions draw attention to something in the image that is not obvious, (C4) such as its relevance to the text. (C5) Captions can consist of a few words of description, or several sentences. (C6) Along with the title, lead, and section headings, (C7) captions are the most commonly read words in an article, (C8) so they should be succinct and informative. (C9) Captions also include a short title or heading of an article in a magazine or newspaper. (C10) Words shown on a cinema or television screen to establish the scene of a story are also called captions. (C11) Captions can also be inserted below/above charts, figures, graphics and tables. (C12) There are several criteria for a good caption. (C13) A good caption clearly identifies the subject of the picture without detailing the obvious. (C14) It is succinct. (C15) It establishes the picture's relevance to the article, (C16) provides context for the picture, (C17) and draws the reader into the article.

Figure 4. Factual Description 
Table 3. Overview of A Factual Description Text Analysis in the textbook Bahasa

Inggris for Senior High School Grade XII (adapted from Humphrey et. al., 2012, p.183)

\begin{tabular}{|c|c|}
\hline \multicolumn{2}{|l|}{ Text 1 Factual Description } \\
\hline \multicolumn{2}{|l|}{ Creating Captions } \\
\hline Social purpose & Describes the characteristic features of particular objects of caption text \\
\hline \multicolumn{2}{|r|}{ с } \\
\hline $\begin{array}{l}\text { Identification } \\
\text { (give a general orientation to } \\
\text { the topic) }\end{array}$ & $\begin{array}{l}\text { (C1) A caption, also known as a cutline, (C2) is a text that appears below an } \\
\text { image. (C3) Most captions draw attention to something in the image that is } \\
\text { not obvious, (C4) such as its relevance to the text. }\end{array}$ \\
\hline $\begin{array}{l}\text { Description } \\
\text { (a simple description of } \\
\text { features or characteristics of } \\
\text { the topic) }\end{array}$ & $\begin{array}{l}\text { (C5) Captions can consist of a few words of description, or several sentences. } \\
\text { (C6) Along with the title, lead, and section headings, (C7) captions are the } \\
\text { most commonly read words in an article, (C8) so they should be succinct and } \\
\text { informative. (C9) Captions also include a short title or heading of an article in } \\
\text { a magazine or newspaper. (C10) Words shown on a cinema or television } \\
\text { screen to establish the scene of a story are also called captions. (C11) } \\
\text { Captions can also be inserted below/above charts, figures, graphics and tables. } \\
\text { (C12) There are several criteria for a good caption. (C13) A good caption } \\
\text { clearly identifies the subject of the picture without detailing the obvious. } \\
\text { (C14) It is succinct. (C15) It establishes the picture's relevance to the article, } \\
\text { (C16) provides context for the picture, (C17) and draws the reader into the } \\
\text { article. }\end{array}$ \\
\hline \multicolumn{2}{|l|}{ Key grammatical features } \\
\hline $\begin{array}{l}\text { Language for expressing } \\
\text { ideas }\end{array}$ & $\begin{array}{l}\text { - relating processes (verb groups) to define, describe and classify } \\
\text { - action processes (verb groups) to describe activities and behaviors } \\
\text { - particular and generalized concrete participants } \\
\text { - detailed noun groups to describe features or characteristics } \\
\text { - circumstances expressed as adverbials to express details (e.g. place, } \\
\text { manner, angle) }\end{array}$ \\
\hline $\begin{array}{l}\text { Language for connecting } \\
\text { ideas }\end{array}$ & $\begin{array}{l}\text { - simple, compound and some complex sentences } \\
\text { - logical relationships of addition expressed through coordinating } \\
\text { conjunctions }\end{array}$ \\
\hline Language for interaction & - statements expressed as declarative clauses with little evaluation \\
\hline $\begin{array}{l}\text { Language for creating } \\
\text { cohesive texts }\end{array}$ & $\begin{array}{l}\text { - lexical cohesion achieved largely by repetition, class/sub-class and } \\
\text { whole/part relations }\end{array}$ \\
\hline
\end{tabular}

To begin with, sample Text 1 (page 34) talks about caption texts. Caption texts become popular in the several television programs providing television captioning among deaf adults and children in order to help them understand and get short prior information they needed (Tyler et. al., 2013). Caption texts become trending topic in Indonesia since social media especially Facebook and Instagram use caption texts on pictures. Not only the information inside the captions easy to understand but also the following pictures which much attractive to show the trending news or stuff in online shop make social media users change their attitude from making long narrative texts into short functional texts such as captions. As one of short functional text genre, caption texts have the purpose to give the readers specific information or to help the readers performs a day-to-day task (Cameron and Myers, 2013). Functional text is used for everyday information and presents information or 
ideas and aims to show, to tell or to persuade the readers (Anderson and Anderson, 1997, p.3). It implies that functional text is generally a text used for a specific purpose. From this genre, students will learn the function of caption texts not only as a cutline under the pictures but also has specific purpose based on their context.

Text 1 shows that the sample text is not a short functional caption text but it is a factual description text which describes the characteristic features of particular objects of a caption. The textbook writers tried to give a point of view of a caption by using description text rather than explain the text type of a caption. The generic structure or pattern of the factual description text is identification and description. The part of Identification gives an introduction about a caption text; meanwhile the part of description describes characteristics of a caption text (see table 3). The grammatical features of the factual description text can be seen in table 3 . There are some language features to express the idea of the factual description text. First, the verb groups of the text use relational processes or the processes of being for building definitions, descriptions and classifying the captions. Figure 4 shows that the relational processes accumulate at the beginning of the text to build a rich description of the captions. Most of the clauses use verb groups such as (is and are) and they relate each other to describe the meaning of a caption itself. In the subsequent phase, verb groups of action processes such as (C3 \& C7) draw and (C11) insert are used to construct the characteristics of captions. Additionally, the processes be have, and some commonly verbs used in relational processes such as $(\mathrm{C} 4)$ relevance, $(\mathrm{C} 9)$ include, (C13) identify and (C15) establish are provided in the text to classify the captions. Second, the subject groups such as (C1) $a$ caption, (C3) most caption, (C4) its, (C5, C7, C9, C11) captions, (C8) they, (C10) words, (C13) a good caption, (C14, C15) are used as the particular and generalized concrete participants. This indicates that Text 1 uses mostly nouns to transfer the meaning of the caption text. But, there is a shift of participants from nouns to personal pronouns which is represented by 'it' and 'they' referring to a caption/captions as the main topic discussed in Text 1. Moreover, some detailed noun groups are used to describe features or characteristics of captions such as (C1) cutline, (C2, C3, C4) text and image, (C5) words and sentences, (C9) magazine and newspaper, (C17) article. Third, the circumstances in a clause are typically expressed by adverbials to express details (e.g. place, angle and manner) and build meaning of the text (Humphrey et. al., 2012). There are two types of adverbials: adverbs and prepositional phrases. Most of the adverbials used in Text 1 are prepositional phrases such as (C2) below an image, (C3) in the image, (C4) to the text, (C6) with the title, lead, and 
section headings, (C7) in an article, (C9) in a magazine or newspaper, (C10) on a cinema or television screen, (C11) below/above charts, figures, graphics, and tables, (C15) to the article, (C16) for the picture, (C17) into the article. Only an adverb (C13) clearly is used in the text to mention the characteristic of captions.

The language features of Text 1 for connecting ideas are presented by independent clauses (C11, C12 and C14), two or more independent clauses (C5, C9, C10 and C13), and some clauses complex (C1, C2), (C3, C4), (C6, C7, C8) and (C15, C16, C17). In addition, a clause can be defined as the largest grammatical unit. A clause complex is two or more independent and dependent clauses logically connected. The coordinate conjunction mostly used in Text 1 'also' (C1, C9, C10, C11) expressed logical relationships of addition and 'such as' (C4) expressed description meaning. The speech function of statements provided in Text 1 expresses declarative clauses. The intensity of modality in Text 1 is low, e.g. (C5, C11) can and (C8) should, in order to be less assertive and less authoritative when describing the features and meaning of captions. Text 1 has linear pattern of the theme. The lexical cohesion of Text 1 is achieved largely by repetition of the subject themes (captions). The theme (captions) is repeated consistently several times with different rheme but they have relational processes of the meaning. Those repetitions are interplay between clause themes and the rest of the clause that sets up linear patterns of caption information flow (Humphrey et. al., 2012, p.137).The text writers adapted this short functional text of caption from en.m.wikipedia.org as a source of the text. By learning the factual description text of captions, students study some verbal meanings of captions. Furthermore, the textbook writers should add some key grammatical features of short functional caption text such as social purpose, the structure of a caption text, language for expressing and connecting ideas. Because photo captions sometimes adopt the characteristics of hard or soft news. The characteristics of hard news deliver key information about current events, while a soft news photo caption appeals to the emotional side and does not directly affect the audience (Park, 2015). The key grammatical features can help the students understand deeper both grammar and meaning of a caption text so that the students can make their own caption texts properly. 
Text 2: Tenants Advised to Obey Regulations on Apartment (Chapter 5, p.68)

(C1) Jakarta: A building architect has advised families planning (C2) to live in an apartment (C3) to study all the relevant regulations prior to moving in (C4) to help prevent unexpected security-related occurrences. (C5) "Tenants must obey certain regulations (C6) when living in an apartment, (C7) which is far different from living in a landed-house," Fendhi Ibuhindar said. (C8) "Tenants of an apartment should abide by regulations (C9) set by the owner of the high-rise building," he added. (C10) "This is important, (C11) especially for a family that has a young child," (C12) he was quoted as saying by okezone.com. (C13) According to him, (C14) the trend of living in an apartment in Jakarta (C15) started only 10 years ago. (C16) Living in an apartment has increasingly become popular. (C17) 'Most of Jakarta's residents are more accustomed to living in a landed house (C18) and when they live in an apartment, (C19) many are not ready for apartment-living habits and regulations. (C20) They have to abandon their mind set of living in a landed-house," he said. (C21) He said that an owner of apartment should also consider aspects of designing and building materials (C22) that are safe for children. (C23) "The quality of building materials should be prioritized," he said. (C24) "Children's safety should be the main concern with regards (C25) to the building materials that are used," he said.

(Adapted from: The Jakarta Post, May 9, 2014)

Figure 5. News Story 
Table 4. Overview of A News Story Text Analysis in the textbook Bahasa Inggris for Senior High School Grade XII (adapted from Humphrey et. al., 2012, p.198)

\begin{tabular}{|c|c|}
\hline \multicolumn{2}{|l|}{ Text 2 News Story } \\
\hline \multicolumn{2}{|c|}{ Tenants Advised to Obey Regulations on Apartment } \\
\hline Social purpose & $\begin{array}{l}\text { Use to chronicle a newsworthy event. News stories are not recounts because } \\
\text { the events in the story are not typically sequenced in chronological order. The } \\
\text { most disruptive event is presented first in the lead and headline, and more } \\
\text { details about this event are presented in the lead development }\end{array}$ \\
\hline \multicolumn{2}{|l|}{ Structure } \\
\hline Headline & Tenants Advised to Obey Regulations on Apartment \\
\hline Lead & $\begin{array}{l}\text { (C1) Jakarta: A building architect has advised families planning (C2) to live } \\
\text { in an apartment (C3) to study all the relevant regulations prior to moving in } \\
\text { (C4) to help prevent unexpected security-related occurrences. }\end{array}$ \\
\hline Lead development & $\begin{array}{l}\text { (C5) "Tenants must obey certain regulations (C6) when living in an } \\
\text { apartment, (C7) which is far different from living in a landed-house," [F] } \\
\text { Endhi Ibuhindar said. (C8) "Tenants of an apartment should abide by } \\
\text { regulations (C9) set by the owner of the high-rise building," he added. (C10) } \\
\text { "This is important, (C11) especially for a family that has a young child," } \\
\text { (C12) he was quoted as saying by okezone.com. (C13) According to him, } \\
\text { (C14) the trend of living in an apartment in Jakarta (C15) started only } 10 \\
\text { years ago. (C16) Living in an apartment has increasingly become popular. } \\
\text { (C17) "Most of Jakarta's residents are more accustomed to living in a landed } \\
\text { house (C18) and when they live in an apartment, (C19) many are not ready } \\
\text { for apartment-living habits and regulations. (C20) They have to abandon their } \\
\text { mind set of living in a landed-house," he said. (C21) He said that an owner of } \\
\text { apartment should also consider aspects of designing and building materials } \\
\text { (C22) that are safe for children. (C23) "The quality of building materials } \\
\text { should be prioritized," he said. }\end{array}$ \\
\hline Wrap-up & $\begin{array}{l}\text { (C24) "Children's safety should be the main concern with regards (C25) to } \\
\text { the building materials that are used," he said. }\end{array}$ \\
\hline \multicolumn{2}{|l|}{ Key grammatical features } \\
\hline $\begin{array}{l}\text { Language for expressing } \\
\text { ideas }\end{array}$ & $\begin{array}{l}\text { - action processes (verb groups) to describe activities and behaviors } \\
\text { - saying verbs (direct or indirect speech/thought) } \\
\text { - verbs group in past tense to retell events } \\
\text { - particular concrete participants } \\
\text { - detailed noun groups to describe features or characteristics, incorporating } \\
\text { a range of adjectival } \\
\text { - emphasis on providing facts and figures such as time, location, age } \\
\text { - circumstances expressed as adverbials to express details (e.g. place, time, } \\
\text { cause, angle) }\end{array}$ \\
\hline $\begin{array}{l}\text { Language for connecting } \\
\text { ideas }\end{array}$ & - compound, complex and some simple sentences to give information \\
\hline Language for interaction & $\begin{array}{l}\text { - indirect affect, judgement and appreciation vocabulary to evaluate } \\
\text { phenomena } \\
\text { - grading vocabulary to intensify descriptions } \\
\text { - figurative language such as simile, metaphor, personification, alliteration, } \\
\text { atypical word combinations, invented words, to attract the reader's } \\
\text { attention, especially in headlines and captions }\end{array}$ \\
\hline $\begin{array}{l}\text { Language for creating } \\
\text { cohesive texts }\end{array}$ & $\begin{array}{l}\text { - marked themes (adverbials and dependent clauses) to set and reset events } \\
\text { in time and place } \\
\text { - use of pronouns for reference } \\
\text { - lexical cohesion achieved largely by synonyms, antonyms, collocation }\end{array}$ \\
\hline
\end{tabular}


Text 2 belongs to a news story. This text talks about the certain regulations on apartment in Jakarta according to [F] Endhi Ibuhindar as an Indonesian building architect. His name represents Indonesian name that might encourage the readers to think of local building apartments in Jakarta. In addition, the textbook writers missed spell and typo his name [F] Endhi Ibuhindar (see figure 5) when adapted the news story text from The Jakarta Post in the textbook. It is very risky when the readers who are the English teachers and students of Senior High School grade XII read and analyze the text to learn the meaning. There will be missing information about him as the main participant who advises the certain regulations on apartment in Jakarta. The news is taken from The Jakarta Post, May 9, 2014. [F] Endhi Ibuhindar said that the trend of living in an apartment in Jakarta started only 10 years ago. It means that in 2004 Jakarta becomes the first place of growing trend apartment in Indonesia. In addition, the growing of apartment building can be seen from the Ascott building apartment group started opening Indonesian properties in 1995 (Hirsh, 2015). In metropolitan Jakarta, an apartment is the dominant criterion in the search for appropriate urban residential upgrading schemes, with accessibility to workplace as the main alternative. Apartment living is quickly becoming a social status symbol as many of the complexes offer very convenient and desired locations, five-star facilities and luxurious interiors, enabling the dwellers a unique city living experience. Depending on the person/family's individual situation and lifestyle, and the ever-increasing time drain of being caught up in long delays due to traffic jams, apartment living near the work place is beginning to make more sense than owning or renting a house.

In addition, since the Indonesian Act no. 20/2011 states that low-cost apartment development is aimed to fulfil housing needs in urban areas with high population density, and it is developed specifically for low-income employees. Thus, the apartments become a living place destiny (Rachmawati, et al., 2018). It is important to note that the source of the text was presented to make the readers aware that this information was taken from a national English-medium newspaper, the Jakarta Post. This genre could grab readers' attention and encourage them to study all the relevant regulations prior when moving to live in an apartment.

Generally news story texts have four sections: headline, lead, lead development, and wrap-up. Those sections bond by grammatical features of the text to express the idea and understand the meaning inside the text. Past tense verbs used to retell the events. The headline news from the table 4 shows that the social purpose of the text is to chronicle a newsworthy 
event about certain regulations when living in an apartment. This event pointed to the tenants as the particular concrete participants in the text. The action verb 'obey' expresses the sensing processes from tenants to the apartment regulation. The headline news uses simple sentence to give brief information and serve the idea of the news story. It is important to note that headline news attracts readers' attention and help them to chop the meaning of the whole information inside the text.

The lead of the news story (see table 4) presents further information of the headline. It also provides detail information such as location 'Jakarta' and participants 'a building architect and families' as the main topic of the news story. Verb groups in present perfect tense 'has advised' is used to tell the event of the text, to describe events that began in the past and are expected to continue, or to emphasize the relevance of past events to the present moment. The text also uses clause complex functioning to create text cohesively presented by the major independent clause and dependent clauses. The major independent clause (C1) is used to express the idea of the text. Meanwhile, the major dependent clauses uses action verbs using 'to infinitive phrases' (C2) to live, (C3) to study and (C4) to help to show the readers that tenants should do several actions when living in an apartment. The complete information expresses verbs of direct speech (C5, C6, C7, C8, C9, C10, C11, C17, C18, C19, $\mathrm{C} 20, \mathrm{C} 23)$ and indirect speech $(\mathrm{C} 13, \mathrm{C} 14, \mathrm{C} 15, \mathrm{C} 16, \mathrm{C} 21, \mathrm{C} 22)$ provided in lead development (see table 4). The text also provides particular concrete participants (C5, C8) tenants, (C7) [F] Endhi Ibuhindar, (C9) the owner of the high-rise building, (C9, C12, C20, $\mathrm{C} 23, \mathrm{C} 25)$ he, (C11) a family, a young child, (C13) him, (C18, C20) they, (C20) their, (C21) an owner of apartment, (C22, C24) children to describe the events. Text 2 have mostly nouns and 'he' as personal pronoun mostly used in the text becomes sayer in the verbal processes, 'family', 'owner', and 'children' are frequently used as receivers.

Similar with Text 1 , there is a shift of participants from nouns to personal pronouns in Text 2. Text 2 uses the personal pronouns to show the personal perspective of [F] Endhi Ibuhindar about apartment in Jakarta. Meanwhile, 'landed-house' (detailed noun groups) mentions three times as comparison of habitual living in landed-house and apartment. From this living habitual in landed-house, the speaker tries to encourage the tenants of apartment to notice the prior regulation, design and building materials in the apartments. Text 2 shows the use of deontic modality, e.g., (C5) 'must' and (C8, C21, C23, C24) 'should' that concern the speaker's assessment of the desirability of an event or situation toward the safety rules of apartment living. The marked themes give the readers a sense of the intensity of the verbal 
processes when the building architect explained some important information about apartment to the tenants. Marked themes often used to mark a new phase in the build-up of the unfolding story, locating characters and events in time and place (Humphrey, Droga \& Feez, 2012, p.133). In this phase of the news story, circumstances of place are used in a sequence of marked themes. Text 2 mostly uses embedded clauses to express the ideational, interpersonal and textual meaning of the text. The embedded clauses is introduced by words called relative pronouns, e.g., (C6, C18) 'when', (C7) 'which', (C11, C21, C22) 'that' as qualifier inside noun group. Those embedded clauses show us that ideas expressed in two separate clauses can sometimes be connected by embedding one clause inside another (Humphrey, Droga \& Feez, 2012, p.66).

Text 3: A Trip to the Botanical Garden (Chapter 9, p.120-121)

(C1) Last Saturday, the 12 grade students went for a trip to the botanical garden. (C2) Some teachers were also with us. (C3) We gathered together in front of the school yard very early in the morning. (C4) It took us about two hours by bus to get there from our school. (C5) At the botanical garden, we did several things. (C6) First, we bought the entrance ticket. (C7) Second, we listened to our teachers' instruction about group activities. (C8) Next, we divided ourselves into groups based on our personal interests. (C9) Then, each group followed the assigned teacher. (C10) We spent the rest of the day with our groups (C11) doing a lot of activities. (C12) It was really a fun day for us.

Figure 6 Factual Recount 
Table 5. Overview of A Factual Recount Text Analysis in the textbook Bahasa Inggris for Senior High School Grade XII (adapted from Humphrey et. al., 2012, p.187)

\begin{tabular}{|c|c|}
\hline \multicolumn{2}{|l|}{ Text 3 Factual Recount } \\
\hline \multicolumn{2}{|l|}{ A Trip to the Botanical Garden } \\
\hline Social purpose & $\begin{array}{l}\text { Tell us 'what happened' by documenting a series of events. It may be used to } \\
\text { record events and observations from field trips and excursions. }\end{array}$ \\
\hline \multicolumn{2}{|r|}{ e } \\
\hline $\begin{array}{l}\text { Orientation } \\
\text { (set a context for } \\
\text { understanding the events } \\
\text { that follow; provides } \\
\text { background information } \\
\text { about who, where, when, } \\
\text { what) }\end{array}$ & $\begin{array}{l}\text { (C1) Last Saturday, the } 12 \text { grade students went for a trip to the botanical } \\
\text { garden. (C2) Some teachers were also with us. }\end{array}$ \\
\hline $\begin{array}{l}\text { Record of events } \\
\text { (recounted in chronological } \\
\text { order) }\end{array}$ & $\begin{array}{l}\text { (C3) We gathered together in front of the school yard very early in the } \\
\text { morning. (C4) It took us about two hours by bus to get there from our school. } \\
\text { (C5) At the botanical garden, we did several things. (C6) First, we bought the } \\
\text { entrance ticket. (C7) Second, we listened to our teachers' instruction about } \\
\text { group activities. (C8) Next, we divided ourselves into groups based on our } \\
\text { personal interests. (C9) Then, each group followed the assigned teacher. }\end{array}$ \\
\hline $\begin{array}{l}\text { Re-orientation } \\
\text { (round off the sequence of } \\
\text { events usually by resetting } \\
\text { events in time) }\end{array}$ & $\begin{array}{l}\text { (C10) We spent the rest of the day with our groups (C11) doing a lot of } \\
\text { activities. (C12) It was really a fun day for us. }\end{array}$ \\
\hline \multicolumn{2}{|l|}{ Key grammatical features } \\
\hline $\begin{array}{l}\text { Language for expressing } \\
\text { ideas }\end{array}$ & $\begin{array}{l}\text { - action processes (verb groups) in the past tense to refer to activities in the } \\
\text { events stage } \\
\text { - particular human and non-human participants (noun groups or pronouns) } \\
\text { to name people, places and things } \\
\text { - circumstances dependent clauses to express details (e.g. place, time, } \\
\text { extent, manner, cause, accompaniment, angle) }\end{array}$ \\
\hline $\begin{array}{l}\text { Language for connecting } \\
\text { ideas }\end{array}$ & $\begin{array}{l}\text { - complex and compound-complex sentences including dependent clauses } \\
\text { of time } \\
\text { - text connectives to sequence events }\end{array}$ \\
\hline Language for interaction & - appreciation (reaction) to evaluate impact of events \\
\hline $\begin{array}{l}\text { Language for creating } \\
\text { cohesive texts }\end{array}$ & $\begin{array}{l}\text { - references to time in theme position } \\
\text { - lexical cohesion showing use of repetition, synonyms and collocation }\end{array}$ \\
\hline
\end{tabular}

Another sample of Text 3 entitled school trip in botanical garden depicts factual recount text. The purpose of this text is to tell the readers about 'what happened' by documenting a series of field trip events to Botanical Garden. Botanical Garden as the place circumstantial provided in the text is not mention specifically by the textbook writers. Indonesia has 27 botanic gardens: five botanical gardens are under the support of the Indonesian Institute of Sciences, while others are managed by local governments and universities, spreading across 20 provinces in 16 ecoregions (Widyatmoko \& Risna, 2017). Different locations of Botanical Gardens affect the different particular species. It means that the students will learn different things and get different information. By looking at the context of situation that this text 
reveals, in which the authors stated that the location of the school is two hours away from the site, it should refer to Bogor Botanical as one of the school trip destinations. The biggest botanical garden in Indonesia is Bogor Botanical Garden. Bogor Gardens were designated to collect valuable plantation seeds ever since the reign of Sri Baduga Maharaja of the Sunda Kingdom, who ruled in the 15 th century. In 1744 a mansion with vast garden was constructed by the Dutch East India Company, VOC, when Bogor was named Buitenzorg, Java's own San Souci. British Governor Sir Stamford Raffles and Lady Raffles were residents of the Buitenzorg Palace in 1811 to 1816, during the British interregnum in the Indonesian islands, and transformed the Gardens into a replica of the famous English Kew Garden. On May 18th 1817, the Garden was established as 'Lands Plantentuin by instruction of then Governor General Van Der Capellen, and since then, this date was set as the Garden's anniversary. Following Indonesian independence, they were renamed into Kebun Raya (Botanical Garden) or 'Hortus Bogoriensis'. Located in Bogor, Indonesia, 60 km south of central Jakarta, with an annual rainfall, they became and continue today as a major scientific centre for Asian and Indonesian flora and economic plants (Jones, 2012).

The generic structure or pattern of the factual recount text consists of orientation, record of events and reorientation. Orientation provides background information such as the time of the event (Last Saturday), location (botanical garden), participant (12 grade students and some teachers) and sets a context for understanding the events (see table 5). The clauses group (C3, C4, C5, C6, C7, C8, C9) are organized as a sequence in time to record the events during filed trip in botanical garden. The text utilizes discourse markers i.e., connectors such as (C6) first, (C7) second, (C8) next, (C9) then these discourse markers connect each clause from the theme and rheme and show the steps to do by the students during their field trip as sequence of events. The theme (we) is repeated consistently several times with different rheme in $\mathrm{C} 3, \mathrm{C} 5, \mathrm{C} 6, \mathrm{C} 7, \mathrm{C} 8, \mathrm{C} 10$ (see figure 6). The theme we function as actors in the action processes of the meaning. The variation of clause simple and clause complex are used to connect the ideas in the text. Action verbs in the past tense (C1) went, (C3) gathered, (C4) took, (C6) did, (C7) bought, (C8) listened, (C9) divided, (C10) followed, (C11) spent, (C12) doing refer to activities in the events stage expressing the ideas of the text. Reorientation completes the sequence of events by resetting events in time (see table 5). In this case, the text writers give appreciation and judgement $(\mathrm{C} 12)$ 'it was really a fun day for us' to evaluate impact of the events. Contrary to Text 1 and Text 2, Text 3 contains mostly pronouns as actors in the material processes, e.g., (C1) the 12 grade students, (C2) some teachers, (C3, Englie: English Learning Innovation, 3(1), 42-69 
$\mathrm{C} 5, \mathrm{C} 6, \mathrm{C} 7, \mathrm{C} 8, \mathrm{C} 10)$ we, $(\mathrm{C} 4, \mathrm{C} 12)$ it, (C9) each group. Text 3 is centrally concerned with actions; there is a foregrounding of human participants 'doing' the actions. The variety of circumstances presented in Text 3 makes the field of the text more coherent of the everyday domain in the context of students' daily activities. In conclusion, Text 3 is trying to show the readers some activities based on instruction by presenting the events using temporal conjunction (C6, C7, C8, C9) to connect each clause of the text. Although Text 3 is categorized as an instructional text, it is using non-procedural instruction (Knapp \& Watkins, 2005; p.159). By analysing each clause used in the Text, Text 3 contains declarative clauses to explain the events during the school trip in Botanical Garden. Text 3 does not belong to the genre of procedural text which has imperative clauses to explain the steps in doing or making something. In addition, Text 3 has no modality, it can be seen from the whole text (see figure 6) that all clauses use action verbs to inform the students activities in Botanical Garden. Therefore, the writers of Text 3 try to tell the readers about students activities during school trip by assisting several steps to equip the readers with the necessary semantic and syntactic clues using temporal conjunction such as (C6) 'first', (C7) 'second', (C8) 'next', (C9) 'then' to access meaning in text.

\section{CONCLUSION}

In this article, the authors have analysed 3 reading texts critically in terms of the ideational, interpersonal, and textual meaning to examine the register variables of the texts. The three texts consist of 54 clauses and 567 words. In this textbook analysis, the verbal text pertains to written text. For in-depth analysis of reading texts in the textbook Bahasa Inggris for Senior High School Grade XII, three texts with different genres, such as a factual description text, a news story and a factual recount, were selected. The authors analyse the social purpose, generic structures and the key grammatical features of each text. The study findings suggested that Text 1 is a factual description text which describes the characteristic features of particular objects of a caption. The textbook writers tried to give a point of view of a caption by using description text rather than explain the text type of a caption. Meanwhile, Text 2 represents as a news story text. The textbook writers missed spell and typo the name of $[\mathrm{F}]$ Endhi Ibuhindar (see Figure 5) when adapted the news story text from The Jakarta Post (May 9, 2014) in the textbook. The readers who are the English teachers and students of Senior High School grade XII will get the unclear information about the main lead character of this news story text. Text 3 is called factual recount text. Although, the 
textbook writers claimed Text 3 is categorized into a procedural text from the use of temporal conjunction (C6) 'first', (C7) 'second', (C8) 'next', (C9) 'then'. Those temporal conjunctions mainly connect the ideas from one clause to another clause rather than as steps in doing or making something. Moreover, Text 3 covers all the clauses using declarative clauses to tell the events during the school trip in Botanical Garden. There is no imperative clauses that showing instructions to do something. Event though three texts are different in text types (genre), they inform that each text has the same macro patterns namely the social purpose, generic structures and the key grammatical features that should be noticed and understood by English learners and teachers. By being aware of the genre and key grammatical features of the text types, the teachers and the students will understand both the grammar and meaning of the studied texts. Based on these findings implication of this study suggests that both teachers and students need to equip with skills in analyzing and reading as well as in critical language awareness analysis. With this in mind, both teachers and students should have the opportunity to engage critically with textbooks as a socio-semiotic agent, for instance.

\section{REFERENCES}

Anderson, Mark \& Anderson, Kathy. (1997). Text Type in English. Macmillan Education LTD.

Bowcher, W. (Ed.). (2012). Multimodal texts from around the world: Cultural and Linguistic insights. Palgrave Macmillan.

Butt, D., Fahey, R., Feez, S., Spinks, S., \& Yallop, C. (1994). Using Functional Grammar. National Centre for English Language Teaching and Research, Macquarie University.

Butt, D., Fahey, R., Feez, S., Spinks, S., \& Yallop, C. (2000). Using Functional Grammar. National Centre for English Language Teaching and Research, Macquarie University.

Cameron, S \& Myers, S. (2013). Comprehending Functional Text: Instruction, Practice, Assessment. Quincy. Mark Twain Media Inc.

Christie, F., \& Derewianka, B. (2008). A functional approach to writing development. In F. Christie \& B. Derewianka (Eds.), School discourse: Learning to write across the years of schooling (pp. 1-29). Continuum.

Christie, F., \& Derewianka, B. (2008). School discourse: Learning to write across the years of schooling. Continuum. 
Coffin, C., \& Donohue, J. (2014). A language as social semiotic-based approach to teaching and learning in higher education, Language learning monograph series. Wiley.

De Joyce, H. S., \& Feez, S. (2016). Exploring Literacies Theory, Research and Practice. Palgrave MacMillan.

Derewianka, B. (2003). Trends and Issues in Genre-Based Approaches. RELC Journal, 34(2), 133-154. https://doi:10.1177/003368820303400202

Feez, S., \& Joyce, H. D. S. (1998). Text-based syllabus design. National Centre for English Language Teaching and Research. Macquarie University.

Gilmore, A. (2015). Research into practice: The influence of discourse studies on language descriptions and task design in published ELT materials. Language Teaching, 48(4),506-530. https://doi:10.1017/s0261444815000269

Halliday, M. A. K. (1975) Learning how to mean: Explorations in the development of language. Edward Arnold.

Halliday, M. A. K., \& Hasan, R. (1989). Language, context and text: Aspects of language In a social-semiotic perspective. Deakin University Press.

Halliday, M. A. K., \& Matthiessen, C. M. M. (2004). An introduction to functional Grammar (3th ed.). Hodder Arnold.

Halliday, M. A. K., \& Matthiessen, C. M. M. (2014). An introduction to functional grammar (4th ed.). Routledge.

Halliday, M. A. K., \& Hasan, R. (1989). Language, context and text: Aspects of language in a social-semiotic perspective. Deakin University Press.

Hasan, R. (1996). What kind of resource is language? In C. Cloran, D. Butt, \& G. Williams (Eds.), Ways of saying: Ways of meaning: Selected papers by Ruqaiya Hasan (pp. 13-36). Cassell.

Hirsh, Max. (2015). The shifting demographics of the serviced apartment industry in South East Asia. South East Asia Research, 23, 2, pp 187-204, https://doi: 10.5367/sear.2015.0256.

Humphrey, Sally et. al. (2012). Grammar and Meaning (New Edition). PETAA.

Jones, David S. (2012). The Penang Botanic Gardens, 1794-1905: the design and development of a tropical botanic garden. Studies in the History of Gardens \& Designed Landscapes: An International Quarterly, 18:2, 145-160, https://doi.org/10.1080/14601176.1998.10435539. 
Knapp, Peter \& Watkins, Megan. (2005). Genre, Text, Grammar: Technologies for Teaching and Assessing Writing. University of New South Wales Press Ltd.

Kontozi, A. (2011). Analysis and evaluation of English 6th grade textbook used in Greek public schools. University of Cyprus, Cyprus, Greek, http://www.academia.edu/3481650/Analysis_and_Evaluation_of_English_6th_Grad e_texttbook_used_in_Greek_public_Schools\%3E

Lim, M. (2007). Exploring social practices in English classes: A qualitative investigation of classroom talk in a Korean secondary school. Unpublished $\mathrm{PhD}$ thesis, University of Adelaide.

Orton, J. (2010). Culture and English materials. In H. P. Widodo \& L. Savova (Eds.), The Lincom guide to ELT materials design and development: Theory and practice (pp. 215-228). Lincom Europa.

Macnamara, B. N., Hambrick, D. Z., \& Oswald, F. L. (2014). Deliberate practice and performance in music, games, sports, education, and professions: A meta-analysis. Psychological Science, 25(8), 1608-1618.

Martin, J. R. (2009). Genre and language learning: A social semiotic perspective. Linguistics and Education, 20(1), 10-21. doi:10.1016/j.linged.2009.01.003.

Martin, J. R., \& Rose, D. (2004). Working with discourse: Meaning beyond the clause. London: Continuum. Martin, J. R., \& Rose, D. (2008). Genre relations: Mapping culture. Equinox.

Martin, J. R., \& Rose, D. (2007). Working with discourse: Meaning beyond the clause, 2nd Edn. Continuum.

Matthiessen, C. M. (1999). The system of TRANSITIVITY: an exploratory study of textbased profiles. Functions of Language, 6(1), 1-51.

Mickan, P. (2006). Socialisation, social practices and teaching. In P. Mickan, I. Petrescu, \& J.Timoney (Eds.), Social practices, pedagogy and language use: Studies in socialisation(pp. 7-23). Lythrum Press.

Mickan, P. (2013). Language curriculum design and socialisation. Bristol, Multilingual Matters.

Mickan, P., \& Lopez, E. (Eds.). (2016). Text-based research and teaching: A social semiotic perspective on language in use. Springer.

Mickan, P. (2017). Text-based research and teaching from a social semiotic perspective: Transformative research and pedagogy. In Text-Based Research and 
Teaching (pp.15-35). Palgrave Macmillan.

Painter, C. (1999) Learning through language in early childhood. Cassell.

Park, Mi-jung. (2015). Semiotic analysis of photojournalism captions: A comparison of Korean-English and Korean-Japanese translations. Perspectives Studies in Translatology. https://doi.org/10.1080/0907676X.2015.1076491.

Putra, D. A., \& Lukmana, I. (2017). Text complexity in senior high school English textbooks: A Systemic functional perspective. Indonesian Journal of Applied Linguistics, 7(2), 436-444.

Rachmawati, Farida et. al. (2018). Critical success factor for partnership in low-cost apartments project: Indonesia perspective. Pacific Rim Property Research Journal, 24:2, 149-160. https://doi: 10.1080/14445921.2018.1461769.

Rose, D. and Martin, J. R. (2012) Learning to write, reading to learn: Genre, knowledge and pedagogy in the Sydney School. Equinox

Schleppegrell, M. J. (2008). The language of schooling: A functional linguistics perspective. Lawrence Erlbaum Associates, Publishers.

Teramoto, H.(2010). New-arrival-ness as social construct: A qualitative case study (Unpublished Doctoral Thesis). The University of Adelaide, Australia.

Tomlinson, B. (Ed.). (2012). Applied linguistics and materials development. Continuum.

Tyler, Michael D et. al. (2013). Effect of Caption Rate on the Comprehension of Educational Television Programmes by Deaf School Students. Deafness \& Education International, 11:3, 152-162, https://doi.org/10.1179/146431509790559606.

Webster, J.J.(2009). An introduction to Continuum Companion to Systemic Functional Linguistics. In M.A.K. Halliday \& J.J. Webster, Continuum companion to systemic functional linguistics (pp.1-11). Continuum.

Widiastuti, R. (2017). A Socio-Semiotic Perspective on a Unit of Work in an Indonesian Textbook. In Text-Based Research and Teaching (pp. 179-192). Palgrave Macmillan.

Widodo, H. P. (2015). The development of vocational English materials from a social semiotic perspective: Participatory action research. (Unpublished $\mathrm{PhD}$ thesis) University of Adelaide, Australia.

Widodo, H. P. (2016). Language policy in practice: Reframing the English language Curriculum in the Indonesian secondary education sector. In English language 
education policy in Asia (pp. 127-151). Springer, Cham.

Widodo, H. P. (2017). A Critical Micro-semiotic Analysis of Values Depicted in the Indonesian Ministry of National Education-Endorsed Secondary School English Textbook. English Language Education, 131-152. https://doi:10.1007/978-3-319$63677-18$

Widyatmoko, Didik \& Risna, Rosniati Apriani. (2017). A Role of Indonesian Botanic Gardens in Achieving Global Strategy for Plant Conservation Goals. Annals of the Missouri Botanical Garden, 102(2):377-385. https://doi.org/10.3417/D-16-00006A.

Williams, G. (2004). Ontogenesis and grammatics: Functions of metalanguage in pedagogical discourse. In G. Williams \& A. Lukin (Eds.), The development of language: Functional perspectives on species and individuals (pp. 241-267). Continuum.

Xuan, W. W. (2017). An exploratory study of ESL writing by junior secondary students in China text type, register and textual features. Functional Linguistics, 4(1). https://doi:10.1186/s40554-016-0038-9 